\title{
Når bør leger ha reservasjonsrett?
}

\author{
Den medisinske utvikling og endrede normer gjør at pasienter $\emptyset$ kende grad får rett til behandlingstilbud som \\ er etisk omstridte. Noen leger opplever at det å utføre eller henvise til slik behandling, innebærer en kren- \\ kelse av deres moralske integritet. Hvilke reservasjonsønsker bør respekteres av samfunnet, og hvordan \\ bør helsetjenesten håndtere reservasjonsretten?
}

\author{
Morten Magelssen \\ magelssen@gmail.com \\ Klinikk for medisin \\ Lovisenberg Diakonale Sykehus \\ og \\ Senter for medisinsk etikk \\ Universitetet i Oslo
}

Olav Magnus S. Fredheim

Nasjonalt kompetansesenter

for sammensatte lidelser

og

Forskningsgruppe smerte og palliasjon

Det medisinske fakultet

Norges teknisk-naturvitenskapelige universitet og

Klinikk for anestesi og akuttmedisin

St. Olavs hospital

Helsepersonell har lovfestet rett til å reservere seg mot å utføre og assistere ved provosert abort. I praksis respekteres også fastlegers reservasjon mot henvisning til abort. Rådet for legeetikk har støttet adgangen til reservasjon også ved forskrivning av prevensjonsmidler som kan skade et befruktet egg, samt ved henvisning til assistert befruktning (1). Legeforeningen har derimot uttalt at legers ønske om reservasjon kun bør respekteres i de tilfellene der det foreligger en lovfestet reservasjonsrett (2).

Diskusjonen om hvilke reservasjonsønsker som bør respekteres, bør ikke alene hente premissene fra dagens lovgivning eller dagens praksis. Siden pasienter får en rett til stadig flere behandlingstilbud som er etisk omstridte, trengs det begrunnede kriterier for å avgjøre hvilke reservasjonsønsker som bør respekteres av samfunnet. I det følgende introduserer vi et slikt rammeverk av kriterier og anvender det på noen aktuelle problemstillinger.

\section{Reservasjonsrettens dilemma}

Når et moralsk omstridt behandlingstilbud er definert som helsehjelp, vil pasienten ha en juridisk rett til det etter pasientrettighetsloven. Dette illustrerer reservasjonsrettens grunnleggende dilemma: På den ene side hensynet til legens samvittighet, og på den andre side pasientens rett til behandling.
De som ønsker å reservere seg, vil alltid utgjøre et mindretall i samfunnet. Dersom flertallet var imot behandlingen, ville den aktuelle behandlingen ikke være tillatt.

Fordi samfunnet har gitt pasienten rett til behandling, har samfunnet selvsagt interesse av å sørge for at retten blir oppfylt. Men samfunnet har også interesse av å beskytte helsepersonellets moralske integritet, spesielt fordi helsetjenesten trenger profesjonsutøvere med høye moralske standarder (3).

\section{Kriterier for reservasjon}

Én av oss (MM) har nylig skissert og argumentert for et sett med kriterier som legers reservasjon bør oppfylle for å skulle respekteres av samfunnet (tab 1) (3). Eksemplet legers reservasjonsrett ved abortinngrep kan illustrere anvendelsen av kriteriene. $\AA$ tvinges til å utføre abort innebærer en alvorlig krenkelse av en dyp og begrunnet overbevisning om at abort er moralsk galt (kriterium $1 \circ \mathrm{og}$ 2). Det å bli tvunget til å delta i noe man finner sterkt uetisk, vil krenke ens moralske integritet. En person har høy grad av moralsk integritet når han har et sett med moralske grunnoppfatninger og i stor grad evner å leve i tråd med disse. Personer med integritet tilstreber sammenheng mellom «liv og lære».
Aborter utgjør en liten del av gynekologers totale arbeidsoppgaver (kriterium 3); fordi kolleger som ikke reserverer seg utfører inngrepet i stedet, blir pasienten ikke skadelidende (kriterium 4), og kolleger og arbeidsgivere blir ikke pålagt uakseptable byrder ved reservasjonen (kriterium 5). Reservasjonsønsket er fundert i den tradisjonelle medisinske og allmennetiske normen om ikke å ta liv (kriterium 6). Selvbestemt abort er fortsatt betydelig omstridt selv om det ikke er en ny prosedyre. Kriterium 7 er derfor delvis oppfylt. Oppsummert ser vi at legers reservasjonsrett ved abortinngrep er velbegrunnet. Det er gode grunner til at samfunnet bør anerkjenne og respektere denne retten.

\section{Reservasjonsønsker som ikke bør respekteres}

Ikke alle ønsker om reservasjon bør respekteres. Hva med en indremedisiner som kommer frem til at han av religiøse grunner ikke kan forordne blodtransfusjoner? Dersom en lege ikke vil yte slik behandling i akuttsituasjoner, kan det sette pasientens liv i fare (kriterium 4). Derfor er slik reservasjon uakseptabel.

En lege som ikke vil behandle en pasient på grunn av pasientens etnisitet, livsstil eller
Tabell 1 Kriterier for vurdering av et reservasjonsønske

Reservasjonsønsket bør respekteres når de følgende kriteriene er oppfylt:

1. Å yte helsehjelpen vil skade legens moralske integritet ved å - utgjøre en alvorlig krenkelse..

... av en dyp overbevisning

2. Reservasjonsønsket har et plausibelt religiøst eller moralsk rasjonale

3. Helsehjelpen ikke anses som en helt sentral del av legens arbeidsoppgaver

4. Byrdene for pasienten er på et akseptabelt lavt nivå

- Pasientens tilstand ikke er livstruende

- Reservasjonen ikke fører til at pasienten ikke får helsehjelpen, eller til uakseptable tidstap eller utgifter

Legen har forsøkt aktivt å minimere byrdene for pasienten

5. Byrdene for kolleger og arbeidsgivere er på et akseptabelt lavt nivå

I tillegg styrkes reservasjonsønsket hvis:

6. Reservasjonsønsket er fundert i sentrale medisinske normer

7. Den aktuelle helsehjelpen er ny eller spesielt moralsk omstridt 
politiske meninger, bør ikke få sitt reservasjonsønske respektert. Grunnen er at det ikke finnes noen plausibel begrunnelse for hvorfor denne bør få reservere seg. Det å skulle yte behandling til en pasient hvis livsstil man misliker, innebærer ikke noen krenkelse av legens egen moralske integritet. En lege bør heller ikke ha anledning til å reservere seg mot å behandle komplikasjoner eller mot å følge opp konsekvenser av behandling som legen har reservert seg mot. For eksempel kan en anestesilege ikke ha anledning til å reservere seg mot å håndtere en akutt anestesikomplikasjon i forbindelse med et abortinngrep, og en fastlege må ikke kunne reservere seg mot å følge opp svangerskapet til en pasient han reserverte seg mot å henvise til assistert befruktning.

\section{Reservasjon mot å henvise}

Hvorvidt reservasjonsretten også skal dekke henvisning til behandling, er omstridt. Intensjonen (formålet) med legens handling og dens bidrag til årsakskjeden som leder frem til den omstridte behandlingen, er etter vårt syn de to avgjørende moralske faktorene.

Ved en skriftlig henvisning bidrar legen klart til årsakskjeden som leder til behandling, og deler intensjonen om at behandlingen skal utføres. Dette kan innebære en alvorlig krenkelse av en dyp overbevisning om at behandlingen er moralsk uakseptabel. Reservasjon mot henvisning bør derfor dekkes av reservasjonsretten.

\section{Krav til legen som reserverer seg}

Leger som ønsker å reservere seg mot behandling eller henvisning som pasienten har rett til, må etter vår mening bidra til at pasienten kan få oppfylt sin rett til helsehjelp hos en annen kollega. Fastleger som ønsker å reservere seg, bør informere kommunen om dette. Videre bør legen - eventuelt i samarbeid med kommunen - ha etablert en velfungerende logistikk for hvordan pasienten kan få sin rett til helsehjelp ivaretatt. I praksis vil det ofte innebære en fast avtale med en kollega i kontorfellesskapet eller i nærheten.

Pasienten bør så tidlig som mulig informeres om at legen vil reservere seg. Dersom pasienten opplyser om kontaktårsaken ved timebestilling, er det trolig mest smidig og skånsomt at pasienten allerede da får informasjon både om legens reservasjon og om hvordan pasienten skal gå frem for å få ivaretatt sin rett til helsehjelp. I de tilfellene legen selv skal formidle sin reservasjon til

Tabell 2 Situasjoner der legers ønske om reservasjon oppfyller kriteriene for velbegrunnet reservasjon og bør respekteres

Provosert abort

Eutanasi og legeassistert selvmord

Prevensjon som virker etter befruktning

Behandling som innebærer destruksjon av overtallige befruktede egg

Assistert befruktning med kjønnscelledonasjon,

der barnets rett til å vokse opp med biologisk mor

og far ikke kan oppfylles

Fosterdiagnostikk med selektiv abort som formål

pasienten, er det viktig at legen gjør dette med omtanke og uten fordømmelse. Hvis pasienten ønsker det, kan gjerne lege og pasient sammen reflektere over de etiske sidene av den aktuelle behandlingen, men i en slik situasjon må legen være særlig varsom og oppmerksom på at han ikke må manipulere pasienten eller påtvinge denne sitt eget syn.

\section{Hvordan håndtere reservasjonsretten?}

Dersom alle legene i et område reserverer seg mot en type behandling eller henvisning, kan det by på praktiske problemer å oppfylle pasientens rett til helsehjelp. Vi mener at kommuner ved nyansettelser i en slik situasjon bør ha anledning til samme praksis som gynekologiske avdelinger har i dag. Gynekologiske avdelinger har rett til å foretrekke jobbsøkere som ikke vil benytte reservasjonsretten hvis dét er nødvendig for fortsatt å kunne tilby abortinngrep (abortforskriften $\S 17$ ). Terskelen for slik forskjellsbehandling av søkere bør være svært høy.

Dersom leger pålegges en plikt til å utføre all behandling og henvisning i de tilfellene der det i dag ikke finnes en lovfestet reservasjonsrett, vil det i realiteten innebære et yrkesforbud for mange leger innen deler av helsetjenesten. For leger som ønsker å reservere seg, vil det å utføre eller henvise til den aktuelle behandlingen innebære en dyp krenkelse av deres moralske integritet. For dem vil det derfor ikke være et reelt alternativ å handle mot sin overbevisning. Den naturlige konsekvensen vil være at de tvinges til å avslutte sitt virke innen den aktuelle grenen av medisinen. Dette er særlig urimelig overfor leger som startet sin legegjerning før pasientene fikk rett til den aktuelle helsehjelpen. I tabell 2
Henvise, forundersøke, gi narkose og utføre

Henvise og utføre

Forskrive og administrere

Henvise og utføre

Henvise og utføre

Henvise og utføre nevner vi noen situasjoner der vi mener det er gode grunner til å respektere legers reservasjonsønsker. Vår tilnærming har vært prinsipiell; få leger - heller ikke vi - ville personlig ønske å reservere seg $\mathrm{i}$ alle disse situasjonene.

\section{Sluttbetraktninger}

Reservasjonsmulighet for helsepersonell handler ikke om å felle en moralsk dom over pasienten eller å hindre pasienten $\mathrm{i}$ å få helsehjelp, men om å få beskytte sin moralske integritet. Det vil vanligvis være mulig å finne smidige løsninger slik at både legens moralske integritet og pasientens rett til behandling blir ivaretatt.

\section{Morten Magelssen (f. 1978)}

er lege med erfaring fra indremedisin, ph.d.-kandidat innen medisinsk etikk og aktiv i Norges kristelige legeforening.

Ingen oppgitte interessekonflikter.

\section{Olav Magnus S. Fredheim (f. 1979)}

er lege i spesialisering i anestesiologi, ph.d. innen smertemedisin og aktiv i Norges kristelige legeforening.

Ingen oppgitte interessekonflikter.

\section{Litteratur}

1. Markestad T, Hytten K. Hvor går grensen for reservasjonsretten? Tidsskr Nor Lægeforen 2010; 130: $1844-5$

2. Bråten KE. Ingen generell reservasjonsrett. Tidsskr Nor Legeforen 2011: 131: 1112

3. Magelssen M. When should conscientious objection be accepted? J Med Ethics 2011; e-publisert 20.6.2011.

Mottatt 1.9. 2011, første revisjon innsendt 29.9. 2011, godkjent 13.10. 2011. Medisinsk redaktør Petter Gjersvik. 